\title{
The Effect of Good Corporate Governance, Cash Flow Volatility and Investment Opportunity Set (Ios) Towards Profit Quality (Empirical Study of Manufacturing Companies on the Indonesia Stock Exchange in 2013-2017)
}

\author{
Ersanti ${ }^{*}$, Dewi Anggraini \\ Postgraduate Program, Masters in Accounting, Mercu Buana University Indonesia
}

\begin{tabular}{ll}
\hline DOI: $10.36348 /$ SJEF.2019.v03i09.006 & | Received: 09.09.2019| Accepted: $17.09 .2019 \mid$ Published: 20.09 .2019
\end{tabular}

*Corresponding author: Ersanti

\section{Abstract}

This study aims to examine the effect of mechanisms good corporate governance (consisting of institutional ownership and managerial ownership), cash flow volatility and investment opportunity set (IOS) on earnings quality. The population in this study was companies with manufacturing types listed on the Indonesia Stock Exchange in the period 2013 to 2017. The sample obtained using the purposive random sampling method was 130 data. Data analysis uses multiple linear regressions. The results showed that the mechanism of good corporate governance does not affect earnings quality, but the volatility of cash flows and investment opportunity set (IOS) affect earnings quality.

Keywords: Good Corporate Governance, Cash Flow Volatility, Investment Opportunity Set (IOS).

Copyright @ 2019: This is an open-access article distributed under the terms of the Creative Commons Attribution license which permits unrestricted use, distribution, and reproduction in any medium for non-commercial use (NonCommercial, or CC-BY-NC) provided the original author and source are credited.

\section{INTRODUCTION}

Profit is a performance indicator that can influence the economic decisions taken by users of financial statements. Profit as part of a financial statement that does not present true facts about the economic condition of the company can be doubted in quality and can mislead the users of the financial statements. Earnings quality can be seen from the benefits for business decision makers of financial statement users and from core earnings [1].

Then, the separation between ownership and management of the company creates conflict. The conflict called agency (agency conflict) is caused by differences in the interests of the agent (management) and the principal (shareholder). In a company, contractual relations between must occur shareholders and company managers [2].

Agency conflicts that often occur in companies can be caused by the lack of monitoring mechanisms between management and shareholders and other parties. The monitoring mechanism that can be used is Good Corporate Governance.

The weak implementation of the implementation of Good Corporate Governance of public companies in Indonesia marked by the lack of transparency in corporate management which results in weak public control and the intervention of majority shareholders in company management that can lead to conflicts of interest that greatly deviate from the norms of Good Corporate Governance [3].

As is the case with the following companies, namely Toshiba Corporation. Toshiba Corporation management especially Toshiba Corporation President and CEO Hisao Tanaka and his predecessor Norio Sasaki made a deviation in recording company profits from 2008. Management inflated total profits of up to 1.2 billion US dollars. This is certainly very fatal for Toshiba Corporation. The markup was forced to be allegedly to attract the interest of investors and creditors, because in fact Toshiba had closed the factory in 2016 ago. This closure occurred because of declining sales due to decreased purchasing power. Reflecting on the case above, the Toshiba factory closure in 2016 might have been prevented earlier if the profits were recorded in real conditions.

From this case it can be seen that since 2008 management has tended to manipulate without making improvements. In addition to management mistakes, accountants also need to get the spotlight in the case of 
profit bubbles. The independent team that conducted the inspection stated that the culture that occurred in the Toshiba Corporation was that subordinates were under pressure to inflate the company's profits. Accountants in this case make the slightest resistance, but if they continue to get pressure they can report it to the Japan Accounting Standards Agency [4].

The occurrence of a conflict called an agency conflict is caused by the separation between ownership and management of the company which causes differences in interests between the agent and the principal. In a company contractual relationship between shareholders (must occur shareholders) and company managers [2].

Research on earnings quality such as Glovita [5] reveals that the lower the quality of earnings the greater the rate of growth of the company the lower the quality of earnings. Similarly, Paramitha Anggia [6] shows that managerial ownership does not have a significant effect on earnings quality but has a significant effect on firm value.

The variable cash flow volatility carried out by Titik Purwanti [3] states that it has no effect on quality. Cash flow volatility indicates another measure of operating environment volatility and greater use of approximation and estimation deviations, by corresponding to greater estimation errors with low earnings quality [7].

Research by Eti Kartina, Nikmah [8] which shows the set of investment opportunities has no significant effect on earnings quality but has a significant effect on firm value.

Investment Opportunity Set (IOS) is a choice of future investment opportunities that can affect the growth of company or project assets that have a positive net present value. Shintawati [9] states that the ratio of equity market value to book value (MVE / BVE) can reflect the existence of IOS for a company. The results of his study concluded that IOS which is proxied by MVE / BVE has a significant effect on firm value. The higher the MVE / BVE ratio the higher the company value. This indicates that companies with high market value are considered good by investors through high stock prices.

Based on the phenomena and previous studies mentioned above, conclusions can be drawn to be examined about the factors that affect the quality of corporate earnings by represented by variables Influence of Good Corporate Governance Mechanisms, Cash Flow Volatility, Total Debt and Investment Opportunity Set (IOS) On Profit Quality.
LITERATURE, FRAMEWORK THINKING AND HYPOTHESES

\section{Reader Review \\ Agency Theory (Theory Agency)}

Agency theory proposed by Jensen and Meckling in 1976. This theory states working relationship between the parties that the shareholders authorize a party receiving authority (agency) is the manager. Jensen and Meckling [2] define agency relationships as follows:

"We define an agency relationship as a contract under which one or more persons (the principal (s)) engage another person (the agent) to perform some service on their behalf which involves delegating some decision making authority to the agent."

According to Scott [10] agency theory is the relationship or contract between the principal and agent, where the principal is the party that employs the agent to perform duties in the interests of the principal, then the agent is the party who runs the principal's interests.

\section{Earnings Quality}

According to Schipper and Vincent [1] in Novianti [11], earnings quality is the sum can be consumed in one period by keeping the company's capability at the beginning and end of the same period. For investors, earnings reports are considered to have information to analyze shares issued by issuers.

\section{Dechows et al. [12] in Wulansari [13] defines earnings quality as follows}

"Higher quality earnings provide more information about the features of a firm's financial performance that is relevant to a specific decision made by a specific decision-maker."

From the above definition, there are three things that must be underlined:

- Quality of earnings depends on the relevant information in making decisions. The definition of earnings quality above is only in the context of a particular decision model.

- Quality of reported earnings figures is seen from whether the information describes the financial performance of a company.

- Quality of earnings together is determined by the relevance of the financial performance that underlies the decision.

According to Dechow et al. [12] in Paramitha [6], to measure earnings quality through discretionary accruals, the used Modified Jones Model is which is calculated by excluding total accruals (TACC) and nondiscretionary accruals (NDACC).

\section{Total Accruals}

Total accruals in this study are defined as the difference between net income before tax (earnings 
before tax) and cash flow from operating activities

(operating cash flow).

$\mathrm{TACC}_{\mathrm{it}}=\mathrm{EBXT}_{\mathrm{it}}-\mathrm{OCF}_{\mathrm{it}}$

Note

TACC $_{\text {it }}$ : Total accruals in year $\mathrm{t}$

$\mathrm{EBXT}_{\mathrm{it}}$ : Net income before tax (earnings before tax / extraordinary items and discontinued operations) in year $\mathrm{t}$

$\mathrm{OCF}_{\text {it }}$ : Cash flow from operating activities (operating cash flow) in year $\mathrm{t}$

Estimation of Parameters Company specific, obtained through the following OLS (regression analysis modelsOrdinary Least Squares):

$\mathrm{TACC}_{\mathrm{it}} / \mathrm{TAi}_{\mathrm{t}-1}=\alpha_{1}\left(1 / \mathrm{TA}_{\mathrm{i}, \mathrm{t}-1}\right)+\alpha_{2}\left(\left(\Delta \mathrm{REV}_{\mathrm{it}}-\Delta \mathrm{REC}_{\mathrm{it}}\right) / \mathrm{TA}_{\mathrm{i}, \mathrm{t}-1}\right)+\alpha_{3}\left(\mathrm{PPE}_{\mathrm{it}} / \mathrm{TA}_{\mathrm{i}, \mathrm{t}-1}\right)+\varepsilon_{\mathrm{it}}$

Note:

TACC $_{\text {it }} \quad$ : Total accruals in year $\mathrm{t}$

$\mathrm{TAi}_{\mathrm{t}-1} \quad$ : Total assets for sample company $\mathrm{i}$ at year end $\mathrm{t}-1$

$\triangle \mathrm{REV}_{\mathrm{it}} \quad$ : Change in revenue of company $\mathrm{i}$ from year $\mathrm{t}-1$ to year $\mathrm{t}$

$\triangle \mathrm{REC}_{\mathrm{it}} \quad$ : Change net receivables (net receivable) of firm i from year $\mathrm{t}-1$ to year $\mathrm{t}$.

$\mathrm{PPE}_{\mathrm{it}} \quad$ : Gross property, plant and equipment company $\mathrm{i}$ in $\mathrm{t}$.

$\varepsilon_{\text {it }} \quad:$ error

\section{Non-Discretionary Accruals}

In non-discretionary accruals using the Modified Jones Model, it is formulated as follows:

$\mathrm{NDACC}_{\mathrm{it}}=\alpha_{1}\left(1 / \mathrm{TA}_{\mathrm{i}, \mathrm{t}-1}\right)+\alpha_{2}\left(\left(\Delta \mathrm{REV}_{\mathrm{it}}-\mathrm{ECREC}_{\mathrm{it}}\right) / \mathrm{TA}_{\mathrm{i}, \mathrm{t}-1}\right)+\alpha_{3}\left(\mathrm{PPE}_{\mathrm{it}} / \mathrm{TA}_{\mathrm{i}, \mathrm{t}-1}\right)$

\section{Note}

NDACCit: Non discretionary accruals in year $\mathrm{t}$

TAi, $\mathrm{t}-1$ : Total assets for sample company $\mathrm{i}$ at year end $\mathrm{t}-1$

$\triangle \mathrm{REV}$ it $\quad$ Changes in Revenue Company from year $\mathrm{t}-1$ to year $\mathrm{t} \triangle \mathrm{RECit}$ : Change in thenet receivablescompany'sfrom year $\mathrm{t}-1$ to year $\mathrm{t}$

PPEit $\quad$ : Gross property, plant and equipment of company i in year $\mathrm{t}$

\section{Discretionary Accruals}

Because total accruals consist of discretionary accruals and non-discretionary accruals, then discretionary accruals can be formulated as follows:can be formulated as follows:

DACCit $=($ TACCit $/$ TAi, $\mathrm{t}-1)-$ NDACCit DACCit $=($ TACCit $/$ TAi, $t-1)-$ NDACCit

Remarks: DACCit: Remarks: DACCit: Discretionary accrualsDiscretionary accruals of the company in the year $\mathrm{i}: \mathrm{t}$.

\section{Good Corporate Governance}

Corporate governance is defined as a company's internal control system that has the goal of managing significant risks to meet its business objectives through securing company assets and increasing the value of shareholders' investments in the long run. Referring to Glovita's research [5], this study uses two mechanisms corporate governance consisting of:

\section{Institutional}

Ownership Institutional ownership means ownership of shares by other institutions, namely ownership by companies or other institutions. The institutional ownership such as insurance companies, banks, investment companies and ownership by other institutions. Institutional ownership has the ability to control management through process monitoring an effective so as to reduce management's actions in managing earnings.

Nabela and Yoandhika [14] state that institutional ownership is the proportion of shares owned by institutions at the end of the year measured by a percentage. Certain percentages of shares owned by an institution can influence the process of preparing financial statements that does not rule out the possibility of actualization according to the interests of management [15].

In this study, institutional ownership is measured by the large percentage of shares owned by institutional investors.

\section{Managerial Ownership}

Diyah Pujiati [16], revealed that managerial ownership is the proportion of shareholders from 
management who actively participates in corporate decision making (directors and commissioners). In the research Glovita Brelian Anggraini [5] uses managerial and institutional ownership. The problem that often arises from this ownership structure is agency conflict, where there is an interest between the company's management as the decision maker maker and the shareholders as the owner of the company. The shareholders as the owner of the company are outside the company so they cannot supervise the company in full. While the manager as a company management is inside the company and fully knows the condition of the company.

\section{Volatility in Cash Flow}

The word volatility of volatility comes from English, which means fluctuations. The definition of fluctuation according to the dictionary according to the big Indonesian dictionary is a symptom that indicates the ups and downs of a value (price) that occurs within a certain period due to the influence of demand, supply and other factors that can cause ups and downs of value (price).

According to [7] in Fanani [17] cash flow volatility is: "Cash flow volatility indicates high uncertainty in the operating environment as indicated by high cash flow volatility."

The cash flow volatility formula according to Sloan [18]; Dechow and Dichev [12] in Purwanti [3]:

$$
\frac{\sigma(C F O)_{j t}}{\text { Total Assets }}
$$

\section{Description}

$\mathrm{CFO}_{\mathrm{jt}} \quad=$ Company operating cash flow $\mathrm{j} \mathrm{t}$ year

Total Assets $_{\mathrm{jt}} \quad=$ Total Assets of the company $\mathrm{j}$ year $\mathrm{t}$

\section{Investment Opportunity Set (IOS)}

Gaver \& Gaver [19] states that the Investment opportunity set is an investment choice in the future that has returned a high enough so that it can boost the value of the company. This is because the value of the company depends on various expenses determined by the company's management in the future.

According to Myers [20], the Investment Opportunity Set (IOS) is the value of the company as a combination of assets in place (assets owned) with investment options (investment options) in the future. Furthermore, the Definition of Investment Opportunity Set (IOS) that investment choices are an opportunity to develop, but some companies cannot implement all investment opportunities in the future.

This study uses the market value to book value of equity (MVE / BVE) as an IOS proxy that refers to the research of Paramitha [6]. Mathematically, the market value to book value of equity (MVE / BVE) is formulated as follows:

MVE / BVE = (number of shares outstanding x closing price) / (total equity)

\section{Thinking Framework}

Research on earnings quality with good corporate governance variables, volatility Cash flow and investment opportunity sets have been carried out previously including Paramitha Anggia [6], Rona Naula [21], Kurniawati [22], Andri and Hanung [23], Lestari S [24], Eti Kartina [8] and Titik Purwanti [3].

The results of Paramitha research [6] that managerial ownership has no effect on earnings quality. However, it is different from the results of Rona Naula
[21] which states that the variable of good corporate governance influences earnings quality.

Then the constitutional ownership variable in Andri and Hanung's research [23] does not affect earnings quality. This is different from Kurniawati's research [22] that the constitutional ownership variable influences earnings quality. Furthermore the cash flow volatility variable in Titik Purwanti [3] research states that it does not affect earnings quality.

Then the investment opportunity set (IOS) variable in Lestari's research [24] suggests that the variable has a significant effect on earnings quality. This is different from research by Eti Kartina and Nikmah [8] which states that the investment opportunity set has no effect on earnings quality.

Based on the previous description and referring to the research of Paramitha [6] and Purwanti [3], the conceptual framework of this study can be described as follows:

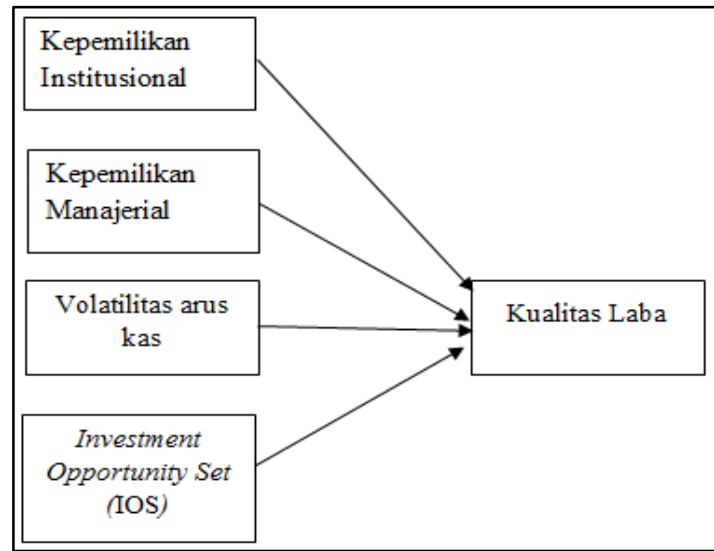

Fig-2.1: Research Framework 


\section{Hypothesis}

From the formulation of the problems raised in this study, the statistical hypotheses which still must be proven are as follows:

$\mathrm{H}_{1}$ : Institutional Ownership affects the quality of earnings.

$\mathrm{H}_{2}$ : Managerial Ownership affects the quality of earnings.

$\mathrm{H}_{3} \quad$ : Cash flow volatility affects earnings quality.

$\mathrm{H}_{4} \quad$ :Investment Opportunity Set affects the quality of earnings.

\section{RESEARCH DESIGN AND METHODS}

\section{Type of}

Research this research is causal research. Causal design is a research design in which the researcher wants to find the cause of one or more problems [25]. Through this study the authors want to see the effect of Good corporate governance, cash flow volatility, Investment Opportunity Set (IOS) on earnings quality.

\section{Definition of Variable Operationalization and Measurement of}

\section{Independent Variables (X)}

In this study there are three independent variables, including:

\section{Good corporate governance}

Corporate governance is a set of mechanisms that influence the decisions made by management when there is a separation of ownership and supervision [26] in Amanita [13]. And in this study there are two mechanisms used namely institutional ownership and managerial ownership.

- Institutional ownership is a percentage of the number of shares owned by other institutions or agencies outside the company Rachmawati and Triatmoko [23]

- Managerial ownership is proxied by the percentage of share ownership by company directors according to Siallagan and Machfoedz's [27] research.

\section{Cash flow volatility Cash flow}

Volatility is the degree of cash flow distribution or distribution index of the company's cash flow distribution [7, 3]. To measure earnings quality, you need stable cash flow information, in the sense of having a small volatility.

The formula of cash flow volatility according to Dechow and Dichev [12] in Purwanti [3]:

$$
\frac{\sigma(C F O)_{j t}}{\text { Total } \text { Assets }_{j t}}
$$

\section{Description}

$\mathrm{CFO}_{\mathrm{jt}} \quad=$ Company operating cash flow $\mathrm{j} \mathrm{t}$ year

Total Assets $_{\mathrm{jt}} \quad=$ Total Assets of the company $\mathrm{j}$ year $\mathrm{t}$

\section{Investment Opportunity Set (IOS)}

According to Myers [20], the Investment Opportunity Set (IOS) is the value of the company as a combination of assets in place (assets owned) with investment options (investment options) in the future. And referring to Paramitha research [6], to measure the Investment Opportunity Set mathematically, the market value to book value of equity (MVE / $\mathrm{BVE}$ ) is formulated as follows:

$$
=\frac{\text { Number of shares outstanding xclosing prices }}{\text { Total Equity }}
$$

\section{Dependent Variable (Y)}

Dependent variable in this study is earnings quality. Earnings quality in this study was measured by discretionary accruals the model Jones [28] in the Paramitha [6] study, which was calculated by excluding total accruals (TACC) and nondiscretionary accruals (NDACC). The calculation model is as follows:

\section{Total Accruals}

Total accruals in this study are defined as the difference between net income before tax (earnings before tax) and cash flow from operating activities (operating cash flow).

$$
\mathrm{TACC}_{\mathrm{it}}=\mathrm{EBXT}_{\mathrm{it}}-\mathrm{OCF}_{\mathrm{it}}
$$

\section{Note:}

TACC $_{\text {it }}$

$\mathrm{EBXT}_{\text {it }}$

$\mathrm{OCF}_{\text {it }}$
: Total accruals in the year $\mathrm{t}$

: Net income before tax (earnings before tax / extraordinary items and discontinued operations) in year $\mathrm{t}$

: Cash flow from operating activities (operating cash flow) in year $\mathrm{t}$ 
Estimates of company specific parameters, obtained through the following OLS (regression analysis models Ordinary Least Squares):

$\mathrm{TACC}_{\mathrm{it}} / \mathrm{TA}_{\mathrm{i}, \mathrm{t}-1}=\alpha_{1}\left(1 / \mathrm{TA}_{\mathrm{i}, \mathrm{t}-1}\right)+\alpha_{2}\left(\left(\Delta \mathrm{REV}_{\mathrm{it}}-\Delta \mathrm{REC}_{\mathrm{it}}\right) / \mathrm{TA}_{\mathrm{i}, \mathrm{t}-1}\right)+\alpha_{3}\left(\mathrm{PPE}_{\mathrm{it}} / \mathrm{TA}_{\mathrm{i}, \mathrm{t}-1}\right)+_{\mathrm{it}}$

\section{Description}

TACC $_{\text {it }} \quad$ : Total accruals on year $\mathrm{t}$

$\mathrm{TA}_{\mathrm{i}, \mathrm{t}-1} \quad$ : Total assets for the sample company $\mathrm{i}$ at the end of year $\mathrm{t}-1$

$\triangle \mathrm{REV}_{\mathrm{it}}$ : Change in revenue of company $\mathrm{i}$ from year $\mathrm{t}-1$ to year $\mathrm{t}$

$\triangle \mathrm{REC}_{\mathrm{it}}$ : Change in net receivables of the company $\mathrm{i}$ from year $\mathrm{t}-1$ to year $\mathrm{t}$

$\mathrm{PPE}_{\mathrm{it}} \quad$ : Gross property, plant and equipment company $\mathrm{i}$ in $\mathrm{t}$

$\varepsilon_{\text {it }} \quad:$ error

\section{Non-Discretionary Accruals}

In non-discretionary accruals using the Modified Jones Model, it is formulated as follows:

$\mathrm{NDACC}_{\mathrm{it}}=\alpha_{1}\left(1 / \mathrm{TA}_{\mathrm{i}, \mathrm{t}-1}\right)+\alpha_{2}\left(\left(\Delta \mathrm{REV}_{\mathrm{it}}-\mathrm{ECREC}_{\mathrm{it}}\right) / \mathrm{TA}_{\mathrm{i}, \mathrm{t}-1}\right)+\alpha_{3}\left(\mathrm{PPE}_{\mathrm{it}} / \mathrm{TA}_{\mathrm{i}, \mathrm{t}-1}\right)$

\section{Note}

$\mathrm{NDACC}_{\mathrm{it}}$ : Non-discretionary accruals in year $\mathrm{t}$

$\mathrm{TA}_{\mathrm{i}, \mathrm{t}-1}$ : Total assets for sample company $\mathrm{i}$ at year end $\mathrm{t}-1$

$\triangle \mathrm{REV}_{\mathrm{it}}$ : Changes in income (income revenue) company $\mathrm{i}$ from year $\mathrm{t}-1$ to year $\mathrm{t} \Delta \mathrm{REC}_{\mathrm{it}}$ : Change in net receivables ofcompany i from year $\mathrm{t}-1$ to year $\mathrm{t}$

$\mathrm{PPE}_{\mathrm{it}}$ : Gross property, plant and equipment of company $\mathrm{i}$ in year $\mathrm{t}$

\section{Discretionary Accruals}

Because total accruals consist of discretionary accruals and non-discretionary accruals, then discretionary accruals can be formulated as follows:can be formulated as follows:

$\mathrm{DACCDACC}_{\mathrm{itit}}=\left(\mathrm{TACC}=\left(\mathrm{TACC}_{\mathrm{itit}} / \mathrm{TA} / \mathrm{TA}_{\mathrm{i}, \mathrm{t}-\mathrm{i} \mathrm{i}, \mathrm{t}-1}\right)-\mathrm{NDACC}\right)-\mathrm{NDACC}_{\mathrm{iti}}$

\section{Information: Remarks}

DACCit: DACCit: Discretionary accrualsDiscretionary accruals company i in year t

\section{Population and Research Samples The}

Population in this study was all manufacturing companies listed on the Indonesia Stock Exchange. This study uses secondary data from the financial statements of manufacturing companies in 2013-2017. The data in this study were taken using the purposive sampling method, with the following criteria:

- Manufacturing companies

- Publish financial statements in rupiah and issue audited financial statements with December 31.

- $\quad$ No delisting during 2013 - 2017.

- Has complete data in accordance with the needs of the author.

\section{DATA COLLECTION TECHNIQUES DATA}

Used in this study are secondary data. The data used in this study is the annual financial statements of each sample company that were reported to the Indonesia Stock Exchange from 2013-2017. Sources of data in this study were obtained through the site owned by the Indonesian Stock Exchange (BEI), which www.idx.co.id

\section{ANALYSIS METHOD}

The analysis method used in this research is quantitative. Data processing and analysis in this study uses multiple regression analysis. The computer software used to process and analyze data is software SPSS 25 (Statistical Package for Social Science).

\section{RESEARCH RESULTS AND DISCUSSION Description of Research Objects}

Based on data obtained from the official website of the Indonesia Stock Exchange or http://www.idx.co.id it is known that the companies that entered the criteria in purposive sampling during the study year (2013-2017) were 26 companies. 


\begin{tabular}{|c|c|c|}
\hline No & Hasil Penentuan Sampel & $\begin{array}{l}\text { Kriteria } \\
\text { Jumlah }\end{array}$ \\
\hline 1 & $\begin{array}{l}\text { Perusahaan manufaktur yang terdaftar } \mathrm{di} \\
\text { Bursa Efek Indonesia }\end{array}$ & 156 \\
\hline 2 & $\begin{array}{l}\text { Perusahaan yang delisting selama tahun } \\
\text { penelitian }\end{array}$ & (4) \\
\hline 3 & $\begin{array}{l}\text { Perusahaan yang menerbitkan laporan } \\
\text { keuangan menggunakan mata uang asing }\end{array}$ & (24) \\
\hline 4 & $\begin{array}{l}\text { Perusahaan yang mempublikasikan } \\
\text { Annual Report tidak lengkap selama } \\
\text { tahun penelitian }\end{array}$ & (27) \\
\hline 5 & $\begin{array}{l}\text { Perusahaan yang tidak memiliki catatan } \\
\text { harga saham pada saat penutupan dan } \\
\text { pendapatan per lembar saham }\end{array}$ & (26) \\
\hline 6 & $\begin{array}{l}\text { Perusahaan yang tidak mempunyai data } \\
\text { yang lengkap mengenai penelitian }\end{array}$ & (49) \\
\hline & Perusahaan yang memenuhi kriteria & 26 \\
\hline & Jumlah sampel (26x5) & 130 \\
\hline
\end{tabular}

\section{Assumptions Test and Instrument Quality}

Research

Analysis used in research descriptive statistical analysis, and multiple regression analysis.

\section{Descriptive Statistics}

\begin{tabular}{|c|c|c|c|c|c|}
\hline \multicolumn{6}{|c|}{ Hasil Uji Statistik Deskriptif } \\
\hline & & \multicolumn{4}{|c|}{ Descriptive Statistics } \\
\hline & Minimum & Maximum & Mean & Std. Deviation & $\mathrm{N}$ \\
\hline DACC & -4.57 & -84 & -2.0789 & .72067 & 130 \\
\hline INST & .7439 & 100 & 1.0673 & 1.08520 & 130 \\
\hline MANJ & -.67 & 76 & 4.3861 & 12.39943 & 130 \\
\hline VOL & .00 & .83 & .1370 & .13207 & 130 \\
\hline 105 & .34 & 1358 & 73.0772 & 359.54904 & 130 \\
\hline
\end{tabular}

\section{Based on the table above, it can be explained}

Profit Quality Variables range in value from 4.57 to -0.84 . The lowest value of -4.57 was owned by the company PT Charoen Pokphand Indonesia Tbk in 2017 and the maximum value of -0.84 by PT DaryaVaria Laboratoria Tbk. The mean or average earnings quality variable is -2.07789 and the standard deviation is 0.72067 .

Descriptive statistical analysis results of Institutional Ownership showed a minimum value of 0.74 by PT Lionmesh Prima Tbk in 2013 and a maximum value of 100 owned by Indocement Tunggal Prakarsa Tbk, Holcim Indonesia Tbk, Arwana Citramulia Tbk, Champion Pacific Indonesia Tbk, Charoen Pokphand Indonesia Tbk, Japfa Comfeed Indonesia Tbk, Astra Otoparts Tbk, PT Selamat Sempurna Tbk, Trident International Tbk, Supreme
Cable Manufacturing \& Commerce, Three Pillars of Prosperous Food Tbk, Delta Djakarta Tbk, Indofood CBP Sukses Makmur Tbk, Multi Bintang Indonesia Tbk, Darya-Varia Laboratoria Tbk, Kalbe Farma Tbk, Tempo Scan Pacific Tbk, Mandom Indonesia Tbk, Unilever Indonesia Tbk from 2013 to 2017. The mean value or average institutional ownership is 1.0673 with a standard deviation of 1.08520 .

The Managerial Ownership Variable shows a minimum value of -0.67 by PT Gudang Garam Tbk in 2016 and a maximum value of 76.00 by PT Berlina Tbk in 2014 and 2015. The mean or average value of managerial ownership is 4.3861 and the standard deviation is 12,40 .

The results of the descriptive statistical analysis of the variable Cash Flow Volatility show a 
minimum value of 0.00 by PT Berlina Tbk in 2017 and a maximum value of 0.83 owned by PT Unilever Indonesia Tbk in 2013. The mean value or average cash flow volatility is 0.1370 and standard deviation of 0.13207 .

\section{Classical Assumption Test Normality Test}

The results of the descriptive statistical analysis of the Investment Opportunity Set (IOS) variable showed a minimum value of 0.34 by PT Gajah Tunggal Tbk in 2015 and a maximum value of 1,358.53 owned by PT Berlina Tbk in 2014. The mean or average IOS value was 73, 0772 and the standard deviation of 359.55 .

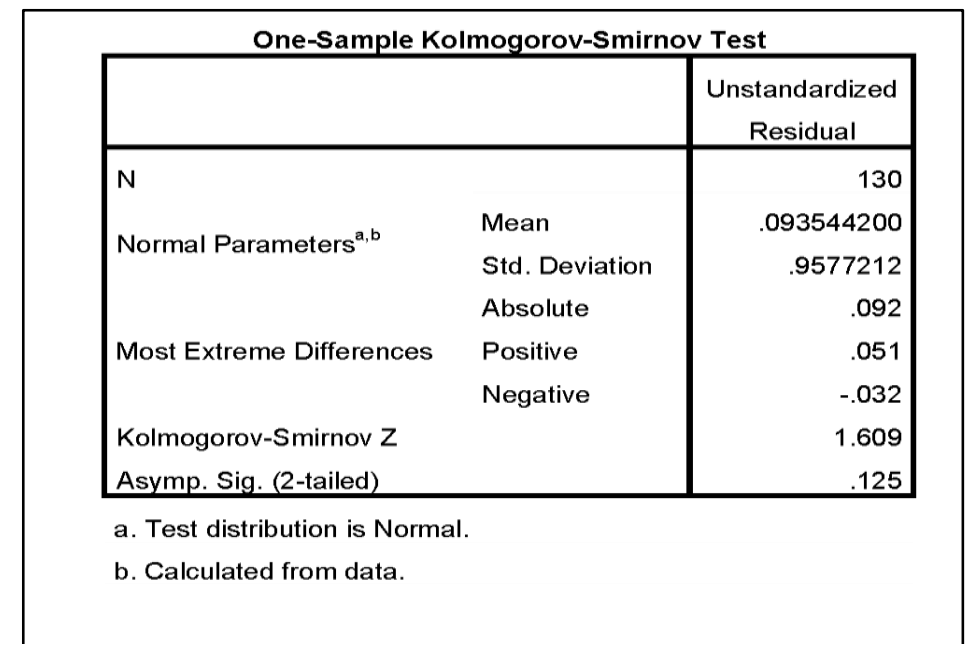

From the results of the above output it can be seen that the Asymp value model. Sig. (2tailed) = 0.125 , then according to the provisions of $0.125>0.05$, the residual value is normal.

Then the data in the model can be said to be

used for further testing. So it can be concluded that the good mechanism variable data is normal. Corporate governance, cash flow volatility and investment opportunity sets that were tested were normally distributed. normally distributed and the regression model can be

\section{Heteroscedasticity Test}

\begin{tabular}{|c|c|c|c|c|c|c|}
\hline \multirow[t]{2}{*}{ Mode } & & \multicolumn{2}{|c|}{$\begin{array}{c}\text { Unstandardized } \\
\text { Coefficients }\end{array}$} & \multirow{2}{*}{ 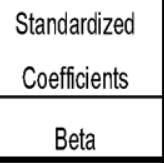 } & \multirow[t]{2}{*}{$T$} & \multirow[t]{2}{*}{ Sig. } \\
\hline & & $B$ & Std. Error & & & \\
\hline \multirow{5}{*}{1} & (Constant) & 1.0013 & .106 & & 1.079 & 1.000 \\
\hline & INST & .030 & .054 & .909 & .731 & 1.020 \\
\hline & MANJ & .127 & .005 & .077 & .065 & .670 \\
\hline & VOL & .005 & .456 & .432 & -3.703 & .910 \\
\hline & IOS & .820 & .000 & .650 & -2.110 & .058 \\
\hline
\end{tabular}

From the results of glacier test it is known that the correlation value of variables with Unstandardized Residuals has a significance value of more than 0.05 . Because the significance is more than 0.05 , it can be seen that the correlation value of variables with Unstandardized Residuals has a significance of more than 0.05 , so it can be concluded that there is no heteroscedasticity problem in the regression model. 


\section{Test Multicollinearity}

\begin{tabular}{|c|c|c|c|c|c|c|c|}
\hline \multicolumn{8}{|c|}{ Coefficients ${ }^{a}$} \\
\hline & \multirow{2}{*}{\multicolumn{2}{|c|}{$\begin{array}{l}\text { Unstandaroized } \\
\text { Coefficients }\end{array}$}} & \multirow{3}{*}{\begin{tabular}{|c|}
$\begin{array}{c}\text { Standardized } \\
\text { Coefficients }\end{array}$ \\
Beta \\
\end{tabular}} & \multirow[t]{3}{*}{ T } & \multirow[t]{3}{*}{ Sig. } & \multirow{2}{*}{\multicolumn{2}{|c|}{ Collinearity Statistics }} \\
\hline & & & & & & & \\
\hline & B & Std. Error & & & & Tolerance & VIF \\
\hline (Constant) & -1.727 & .106 & & -16.355 & .000 & & \\
\hline INST & -.054 & .054 & -.081 & -1.003 & 318 & .990 & 1.010 \\
\hline MANJ & -.001 & .005 & -.018 & -.215 & .830 & .916 & 1.092 \\
\hline VOL & -1.930 & .456 & -.354 & -4.229 & .000 & .919 & 1.088 \\
\hline IOS & .000 & .000 & -.178 & -2.059 & .042 & .862 & 1.161 \\
\hline \multicolumn{8}{|c|}{ endent Variable: DACC } \\
\hline \multicolumn{8}{|c|}{ Sumber: data diolah dengan SPSS 25 (2019) } \\
\hline
\end{tabular}

Testing multicollinearity seen from the value of tolerance and VIF (variance inflation vector, if the tolerance value $>0.01$ or $\mathrm{VIF}<10$, it can be said that there is no multicollinearity. Based on the results of the output shows that the value of the independent variable values tolerance $<0.01$ and VIF> 10 , thus it can be said that multicollinities occur, but this often happens in studies that use multiplicative regression models because multicollinearity can be caused by the effect of a combination of two or more independent variables [29]

\section{AutocorrelationThe autocorrelation}

Testtest aims to test whether in the linear regression model there is a correlation between the error of disturbance in period $t$ and error of disturbance in period $\mathrm{t}-1$ or the previous period in this study autocorrelation was tested with Durbin-Watson (DW Test) [29]. Knowing whether or not there is a correlation is as following:

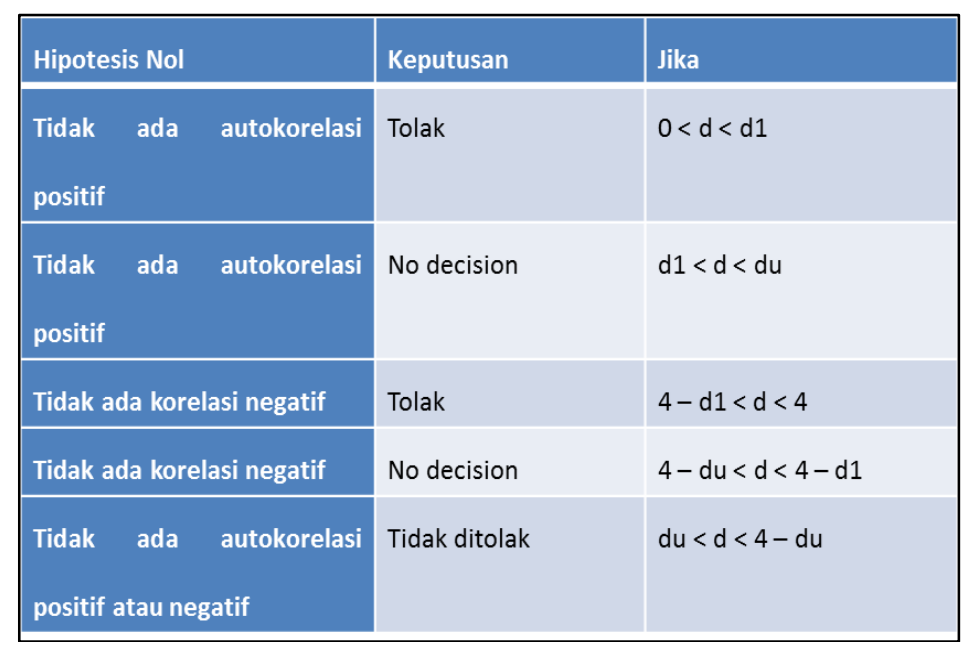

\begin{tabular}{|c|c|c|c|c|c|}
\hline \multicolumn{6}{|c|}{ Model Summary ${ }^{b}$} \\
\hline Model & $R$ & R Square & $\begin{array}{c}\text { Adjusted R } \\
\text { Square }\end{array}$ & $\begin{array}{c}\text { Std. Error of the } \\
\text { Estimate }\end{array}$ & Durbin-Watson \\
\hline 1 & $.443^{\mathrm{a}}$ & .196 & .171 & .65634 & 1.812 \\
\hline \multicolumn{6}{|c|}{ a. Predictors: (Constant), IOS, INST, VOL, MANJ } \\
\hline ber: & ahd & gan SPS & $5(2019)$ & & \\
\hline
\end{tabular}


From the results of the above output, the DW value generated from the regression model is 1,812 . Then the value is compared with $\mathrm{dl}$ and $\mathrm{du}$. From the durbin-watson table with a significance level of $5 \%$ and for $\mathrm{n}=130, \mathrm{k}=4$ is obtained $\mathrm{dl}=1.6508, \mathrm{du}=1.7774$.
With the above data then calculated and compared with the table durbin-watson is 1,812 between du and $4 \mathrm{du}$, ie $1.7774<1.812<2.22226$, the null hypothesis is accepted, which means there is no autocorrelation in the regression.

\section{Hypothesis Testing the}

\section{Determination Coefficient Analysis (R2)}

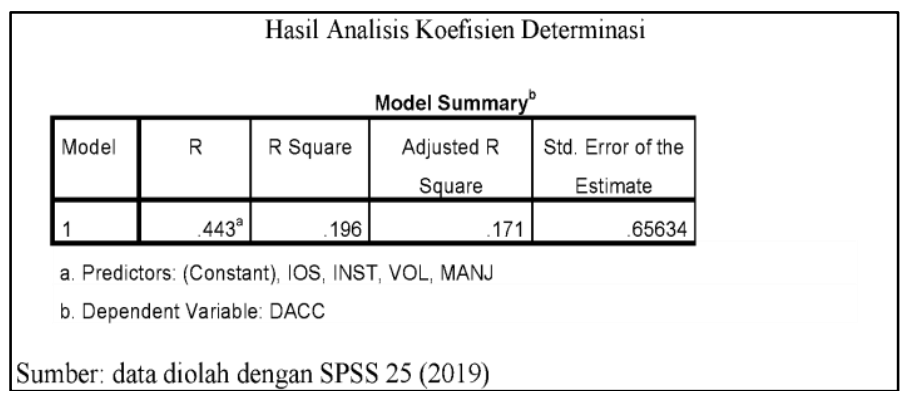

Based on the results of the analysis above shows that the value of that Adjusted $R$ Square17.1 is 0.171 , this means\% of the dependent variable in this study is Profit Quality can be explained by the variable mechanism of Good Corporate Governance, Cash Flow Volatility and Investment Opportunity Set (IOS) is $17.1 \%$, while the rest $(100 \%-17.1 \%=82.9 \%)$ is explained by other factors outside this study.

\section{Simultaneous Regression Coefficient Test (Test F)}

\begin{tabular}{|c|c|c|c|c|c|c|}
\hline \multicolumn{7}{|c|}{ Hasil Uji F } \\
\hline \multicolumn{7}{|c|}{ ANOVA $^{\mathrm{a}}$} \\
\hline & & Sum of Squares & df & Mean Square & $\mathrm{F}$ & Sig. \\
\hline \multirow{3}{*}{1} & Regression & 13.150 & 4 & 3.288 & 7.632 & $.000^{b}$ \\
\hline & Residual & 53.848 & 125 & .431 & & \\
\hline & Total & 66.998 & 129 & & & \\
\hline \multicolumn{7}{|c|}{ a. Dependent Variable: DACC } \\
\hline \multicolumn{7}{|c|}{ b. Predictors: (Constant), IOS, INST, VOL, MANJ } \\
\hline
\end{tabular}

Probvalue. The calculated $\mathrm{F}$ (sig.) In the above table is 0.00 less than the 0.05 significance level so that it can be concluded that the estimated linear regression model is appropriate to be used to explain the Effect of
Mechanisms Good Corporate Governance, Cash Flow Volatility and Investment Opportunity Set on Quality Profit and it can also be said that all independent variables jointly influence the dependent variable.

\section{Regression Coefficient Test (t Test)}

\begin{tabular}{|c|c|c|c|c|c|c|}
\hline \multicolumn{7}{|c|}{$\begin{array}{l}\text { Hasil Uji Koefisien Regresi } \\
\text { Coefficients }^{\mathrm{a}}\end{array}$} \\
\hline \multirow[t]{2}{*}{ Mod } & & \multicolumn{2}{|c|}{$\begin{array}{l}\text { Unstandardized } \\
\text { Coefficients }\end{array}$} & \multirow{2}{*}{$\begin{array}{l}\text { Standardized } \\
\text { Coefficients } \\
\text { Beta }\end{array}$} & \multirow[t]{2}{*}{ T } & \multirow[t]{2}{*}{ Sig. } \\
\hline & & B & Std. Error & & & \\
\hline \multirow{5}{*}{1} & (Constant) & -1.727 & .106 & & -16.355 & .000 \\
\hline & INST & -.054 & .054 & -.081 & -1.003 & 318 \\
\hline & MANJ & -.001 & .005 & -.018 & -215 & .830 \\
\hline & VOL & -1.930 & .456 & -354 & -4.229 & .000 \\
\hline & IOS & .000 & .000 & -.178 & -2.059 & .042 \\
\hline
\end{tabular}


The regression equation is as follows

DACC $=-1.727-0.054$ INST -0.001 MANJ $-1,930$

$$
\mathrm{VOL}+0,000 \mathrm{IOS}+\varepsilon
$$

Based on the results of the analysis table using the t test, it can be concluded:

- A constant of $-1,727$ means that if the value of the Good Corporate Governance Mechanism, Cash Flow Volatility and Investment Opportunity Set is 0 , the Profit Quality value is $-1,727$.

- The regression results show the value of the Institutional Ownership variable of -0.054 . This means that for every 1 unit increase in the level of institutional ownership, it can reduce the value of discretionary accruals by 0.054 , so that the quality of earnings rises assuming other independent variables remain. The variable of institutional ownership has a significance probability value of 0.318> 0.05 which means that institutional ownership has no effect on earnings quality.

- The regression coefficient shows the value of the Managerial Ownership variable of -0.054 . This means that each increase in 1 unit of managerial ownership level, it can reduce the value of discretionary accruals by 0.054 , so that the quality of earnings rises assuming other independent variables remain. Managerial ownership variable significance level of 0.830 is greater than 0.05 , so it can be concluded that managerial ownership does not have a significant effect on earnings quality.

- The regression coefficient shows the value of the variable Cash Flow Volatility of $-1,930$. This means that for every 1 unit increase in the level of cash flow volatility, it can reduce the value of discretionary accruals by 1.930 , so that earnings quality rises assuming the other independent variables remain constant. The variable cash flow volatility has a significance value of 0,000 less than $0.05(0,000<0.05)$. So it can be concluded that cash flow affects earnings quality volatility.

- The regression coefficient shows the value of the Investment Opportunity Set (IOS) variable of 0,000 . This means that for every 1 unit increase in the Investment Opportunity Set (IOS) level, it can increase the value of discretionary accruals by 0,000 , so that earnings quality goes down assuming the other independent variables remain constant. The Investment Opportunity Set variable has a significance value of 0.042 which is smaller than $0.05(0.042<0.05)$. So it can be concluded that the Investment Opportunity Set has a significant effect on earnings quality.

\section{DISCUSSION ON THE \\ Effect of Institutional Ownership on Earnings Quality}

Regression results in this study indicate that the variable Institutional Ownership has no effect on earnings quality. It can be concluded that the first hypothesis (H1 is rejected). It can also be interpreted that the institutional ownership variable does not affect earnings quality. The possibility that institutional ownership does not affect the quality of earnings does not originate from the many levels of institutional ownership in the company, but from the less optimal level of supervision. According to Dewi [30], company performance can be influenced by institutional ownership which, based on the theory, states that institutional ownership will encourage more optimal oversight. Also, institutional investors have a primary focus on market response through increasing share prices so that institutional ownership with earnings quality is unrelated.

The results of this study are in line with Glovita [5] which states that institutional ownership has no effect on the quality of corporate earnings. The accounting statements contained in the financial statements are the responsibility of management for the management of the company's resources. Institutional ownership will use the financial statements as a basis for making decisions without having the power to influence what management reports in the financial statements. Financial statements are a product of management so that institutional ownership outside the company cannot influence what management reports in the financial statements including earnings quality. Other research that is in line, namely Andri and Drs Hanung [23] states that institutional ownership has no effect on earnings quality (discretionary accrual).

However, this study does not support the results of research by Givoly et al. [5] which states that public ownership of shares will improve the quality of corporate earnings.

\section{Effect of Managerial Ownership on Earnings Quality The}

The results of this study indicate that Managerial Ownership has no effect on earnings quality measured by discretionary accruals. The reason managerial ownership does not affect earnings quality is because management ownership is so small that management is less able to influence decision making in running company operations. Then, pressure from the capital market causes companies to choose accounting methods to increase company profits to attract capital from outside even though it does not actually reflect the actual state of the company's economy [24].

The results support the research by Paramitha Anggia [6] which states that managerial ownership has no effect on earnings quality. With a very small number of shares, the conflict of interest between the owner and the manager is not over. Managers will still be motivated to do earnings management to meet their welfare. Thus, the greater managerial ownership will be prone to management actions to engineer earnings on the financial statements which cause the earnings quality on the report to be low or not reflect the real 
conditions because the manager's actions tend to use company accruals to report higher profits [27].

However, the results of this study are not in line with the results of research by Eti Kartina [8] which states that managerial ownership influences the quality of earnings received, which means that the greater the ownership of shares owned by managerial companies, the quality of reported earnings more qualified so that the market responds to announcements from reports profit is getting better [31], this may be due to the managerial as well as the manager as well as the owner so that in running the company more careful.

\section{Effect of Cash Flow Volatility on Earnings Quality}

The results of tests on the variable cash flow volatility show that it has a negative effect on earnings quality. Which means it is indicated that the higher the fluctuations in cash flow of a company, it will reduce the quality of the profits generated. Cash flows that fluctuate sharply will cause difficulties in predicting future cash flows. To measure earnings quality, we need stable cash flow information, in the sense of having a small volatility. This study supports research by Zulfiqar and Poppy [32] which shows that there is a significant influence between cash flow volatility on earnings quality.

The results of this study do not support research conducted by Fanani, et al. [17] who found evidence that states that cash flow volatility has no significant effect on earnings quality. Other research that does not support the Titik Purwanti [3] states that cash flow volatility does not significantly earnings quality.

\section{The influence of Investment Opportunity Set on Profit Quality The}

The results of this data processing show that the Investment Opportunity Set has a positive effect on earnings quality. The results of this data processing which means that the Investment Opportunity Set has a positive effect on earnings quality. Then it can be concluded that IOS has a significant positive effect on earnings quality as measured by discretionary accruals, which means companies with high investment opportunity set levels are likely to have high growth prospects for the company in the future resulting in earnings quality that is beneficial for decision making.

The results of this data processing are not in line with Kartina and Nikmah [8] which states that the Investment Opportunity Set (IOS) has no effect on earnings quality, meaning that the market does not consider investment spending as a matter of consideration in determining the quality of earnings announced by the company.

\section{CONCLUSIONS AND SUGGESTIONS Conclusions}

Based on the results of the analysis conducted in this study it can be concluded that:

- Institutional Ownership has no effect on earnings quality.

- Managerial ownership does not affect the quality of earnings.

- Cash flow volatility affects the quality of earnings.

- Investment Opportunity Set (IOS) affects the quality of earnings.

\section{Suggestions}

This study has several limitations that may result in imperfect research results. Therefore, researchers propose suggestions as follows:

- Further researchers are advised to take samples in other types of industries outside of manufacturing.

- There are several types of earnings quality measurement, but this study only uses one proxy so that the results may also be different if measured using another proxy.

- This study only uses independent variables, namely the mechanism of good corporate governance (managerial ownership and institutional ownership), cash flow volatility and investment opportunity set. Future studies are expected to add other independent variables that can affect earnings quality.

\section{Limitations}

The results of this study have the following limitations:

- This study only uses manufacturing companies as samples so caution is needed in making generalizations.

- The approach to measuring earnings quality uses only one approach, namely the accrual approach.

\section{REFERENCES}

1. Schipper, K., \& Vincent, L. (2003) "Earnings quality". Accounting Horizons, 17, 97-110.

2. Jensen, M. C., \& Meckling, W. H. (1976). Theory of the firm: Managerial behavior, agency costs and ownership structure. Journal of financial economics, 3(4), 305-360.

3. Purwanti P. (2010). Analysis of the effect of cash flow volatility, accrual magnitude, sales volatility, leverage, operating cycle, company size, company age, and liquidity on earnings quality. UNSPostgraduate Prog. Accounting Studies-S.43070362010. Thesis S2, Sebelas Maret University.

4. Gahani, P., Wayan, I. (2017). Effect of Company Size, Leverage and Good Corporate Governance on Profit Quality. E-Journal of Accounting, Univ. Udayana, 19(1), 137-167.

5. Glovita. (2010). The Effect of Managerial Ownership, Institutional Ownership, Leverage, and Growth on Company Profit Quality. Master's Thesis, Sebelas Maret University Surakarta. 
6. Paramitha, A.P., Abdul, R.(2012). Analysis of the Influence of Investment Opportunity Set, and Corporate Governance mechanisms on earnings quality and firm value. Diponegoro Journal of Accounting, 1(2), 1-14.

7. Dechow, PM, Wei, G., \& Schrand, C. (2009) "Understanding earnings quality: A review of the proxies, their determinants and their consequences". Manuscript, edited by M. Hanlon. University of Noter Dame.

8. Kartina, E., \& Nikmah. (2011). The Effect of Corporate Governance, Investment Opportunity Set (IOS) on Profit Quality and Company Value. Journal of Accounting, 1, 92-121.

9. Shintawati, R., Hernawati, \& Indraswati, D. (2011). Lipid Level of Middle-Aged Female Mice Swiss Webster after Pare Juice Momordica charantia L. Administration. Majalah kedokteran bandung-mkbbandung medical journal, 43(2), 93-97.

10. Scott, R. W. (2015). Financial Accounting Theory. Seventh Edition. Pearson Prentice Hall: Toronto.

11. Nuraini, E. (2012). The Effect of Institutional Ownership and Company Size on Debt Policy and Company Value (Empirical Study of Manufacturing Companies Listed on the IDX). Journal of Business and Economics (JBE), 19(2), 110-115.

12. Dechow, P., Ge, W., \& Schrand, C. (2010). Understanding earnings quality: A review of the proxies, their determinants and their consequences. Journal of accounting and economics, 50(2-3), 344-401.

13. Yushita, A. N., \& Triatmoko, H. (2013). Pengaruh mekanisme corporate governance, Kualitas auditor eksternal, dan likuiditas terhadap kualitas laba. Jurnal Economia, 9(2), 141-155.

14. Nabela, Y. (2012). The Effect of Institutional Ownership, Dividend Policy and Profitability on Debt Policy in Property and Real Estate Companies in the Indonesia Stock Exchange. Journal of Management, 1, 1-8.

15. Boediono, G. (2005). Earnings Quality: Study of the Effect of Corporate Governance Mechanisms and the Impact of Earnings Management Using Path Analysis. Accounting National Symposium (SNA) VIII Solo.

16. Diyah, P., \& Erman, W. (2009). "Effect of Ownership Structure on Company Value: Financial Decisions as Intervening Variables. "Journal of Business Economics and Venture Accounting, 12(1), 71-86.

17. Fanani, Z. (2010). Analisis faktor-faktor penentu persistensi laba. Jurnal Akuntansi dan Keuangan Indonesia, 7(1), 109-123.

18. Sloan, R. G. (1996). Do stock prices fully reflect information in accruals and cash flows about future earnings?. Accounting review, 289-315.
19. Gaver, J.J., \& Gaver, K.M. (1993). "Additional Evidence on the Association between the Investment Opportunity Set and Corporate Financing, Dividends, and Compensation Policies". Journal of Accounting and Economics, 1(6), 125-160.

20. Myers, S.C. (1977). Capital of Corporate Borrowing. Journal of Financial Economics, 5, 147-175.

21. Oktaviani, R.N. (2015). The Effect of Good Corporate Governance on Earnings Quality with Earnings Management as an Intervening Variable. SOROT Journal, 10(1).

22. Kurniawati, S.E., M. A.K. (2015). The Effect of Good Corporate Governance Mechanisms, Investment Opportunity Sets (IOS) and Company Size on Profit Quality.

23. Andri, R., \& Hanung T. (2007). "Analysis of Factors That Affect Profit Quality and Company Value". Makassar National Accounting Symposium X, July 26-28.

24. Lestari, S. (2016). The Effect of Investment Opportunity Set, Liquidity and Good Corporate Governance on the Quality of Earnings in the Company.

25. Hari, S., \& Mutia, N. (2014). "The Effect of Implementation of Good Corporate Governance and the Effectiveness of Internal Control System Disclosure of Environmental accounting and Its Implications on the Company Performance."

26. Sloan, R. G. (1996). Do stock prices fully reflect information in accruals and cash flows about future earnings?. Accounting review, 289-315.

27. Siallagan, H., \& Mas'ud, M. (2006). "Mechanisms of Good Corporate Governance, Profit Quality and Company Value, "Padang IX National Accounting Symposium, 2006.

28. Indonesian Institute of Accountants. (2010). Financial Accounting Standards. Jakarta: Salemba Empat

29. Ghozali, I., \& Ratmono, D. (2013). Analisis multivariat dan ekonometrika: teori, konsep, dan aplikasi dengan EVIEWS 8. Semarang: Badan Penerbit Universitas Diponegoro.

30. Ridha, M. (2018). Effect of Good Corporate Governance Mechanisms on Profit Quality (ASEAN Cross Country Study). Master's Thesis, Mercu Buana University.

31. Martadi, I. F., \& Suranta, S. (2006). Persepsi Akuntan, Mahasiswa Akutansi, Dan Karyawan Bagian Akutansi Dipandang Dari Segi Gender Terhadap Etika Bisnis Dan Etika Profesi. Simposium Nasional Akuntansi, 9, 23-26.

32. Gall, C. (2014). The wrong enemy: America in Afghanistan, 2001-2014. HMH. 